\title{
Globalization and Decentralization Forces in China's Higher Education Administration and Management Reform (1953-2015): A Neo-institutional Analysis
}

\author{
Jian Li, Juan Du \\ Indiana University Bloomington, Bloomington, USA
}

\begin{abstract}
From a neo-institutional perspective, this paper investigates the function and interaction of globalization and decentralization in China's higher education administrative reform. Both the internal and external environments have shaped educational forms and functions. It is not increasingly difficult to understand the impact of globalization of higher education in the Chinese historical context of higher education changes. But it has become more controversial to discuss the decentralization and globalization of higher education administration in terms of the coexistence of Soviet model and the Western model, which provide the scope of transitions from centralization to decentralization in China's higher education system. This research suggests that by coordinating the relationship between central and local dual administrative powers, enlarging provincial autonomy, enhancing the decision-making power of higher education administration, and expanding the autonomy of universities and institutions, China's central government can rationally deal with the globalization and decentralization forces in higher education administrative and management reforms.
\end{abstract}

Keywords: neo-institutional analysis, globalization, China's higher education reform, decentralization of higher education

\section{Introduction}

China has accelerated its endeavor to pursue the global economic collaboration and the past three decades have seen the vigorous development of China's higher education reforms. "Globalization and the evolution of the knowledge-based economy have caused dramatic changes to the character and the functions of higher education in most countries around the world" (Mok, 2002, p. 1). In accordance with such pressures from demands, decentralization, privatization, and marketization have become increasingly significant pathways in universities' governances and management. Additionally, the accountability and efficiency of educational resource allocation have always stimulated the restructuring and reforming of higher education systems, according to the prominent international economic trends. From a conceptual perspective, the neo-institutional analysis can provide a profound overview of China's higher education administrative and management reforms. Therefore, this research utilizes the neo-institutional theory to analyze the higher education administration and management reforms in contemporary China. The assumption of this research is related to internal, external,

Jian Li, Ph.D. candidate, School of Education, Indiana University Bloomington. Juan Du, M.A. candidate, School of Education, Indiana University Bloomington. 
and interplay factors in terms of the conceptualizing theoretical framework. Specifically, decentralization is considered as China's governmental internal pressure for higher education reforms of administration and management, and globalization is regarded as the international pressure from worldwide challenges. Moreover, in the neo-institutional framework, the divided periodization of internal, external, and interplay of three forces has been utilized to analyze the trend of China's higher education administration and management.

The research questions are associated with internal, external, and interplay of three forces as follows:

1. How can we divide these three periods, accounting for internal, external, and interplay of three forces and how to describe, explain, and analyze divided periodization?

2. How can we characterize and evaluate the different phases of higher education reform?

3. To what extent do the concepts of decentralization and globalization help us understand different phases of higher education reform, and to what extent can we understand the phases as responses to the Soviet model and the Western style or to the importance of a "market liberal ideology"?

4. How can neo-institutional theory help us explain and understand the patterns of Chinese higher education reform?

\section{Defining Globalization}

Defining the term of globalization involves in different categories and dimensions, including economics, technology, politics, and culture. More specifically, Stromquist and Monkman (2000) pointed out that "globalization is a phenomenon that comprises multiple and drastic changes in all areas of social life, particularly economics, technology, and culture" (p. 1). Gibson-Graham (2006) indicated that globalization is:

A set of processes by which the world is rapidly being integrated into one economic space via increased international trade, internationalization of product and financial markets, the internationalization of a commodity culture promoted by an increasingly networked global telecommunications system. (p. 120)

Additionally, Castells (2000) identified sources of competitiveness in global economy four distinct processes: the technological capacity; access to large, integrated, and affluent market; profitable differential between production costs; and production sets.

From the education perspective, more and more schools are in cooperation with some companies and business. Globalization is creating forces that will divide people economically, but it might also generate forces with the potential to offer new bases for solidarity. (Kenway, 1997, p. 123)

"One of the paradoxes of globalization is that difference is becoming increasingly normative" (McGuire \& Mauro, 1997, p. 3). Actually, the national identities and cultural belongings are changed by the trend of globalization and international migration flows. Multicultural countries are calling forth a new productive educational agenda.

From a comparative conceptual perspective, the concept of globalization is intertwined with the internalization in global context. Specifically, Knight (2002) argued, "Internalization at the national, sector, and institutional levels is defined as the process of integrating an international, intercultural, or global dimension into the purpose, functions or delivery of postsecondary education" (p. 21). However, the trend of globalization has involved in dynamic changes in the worldwide higher education schemes. Generally speaking, globalization has emerged in the development of internationalization and is still comprehensively controversial to define the term of globalization with different academic, cultural, political, and economic perspectives in contrast to the term of internationalization. Specifically: 
Globalization is a phenomenon of a process which is affecting many sectors and disciplines and education is no exception. Internationalizations of higher education are both a response to globalization as well as an agent of globalization. Internationalization is changing the world of higher education and globalization is changing the process of internationalization. (Knight, 2003, p. 38)

Moreover, the term of globalization involves in global competitiveness, intensified collaboration across nations, and boundaries in contrast to internationalization with domination of governments and states. From a historical perspective, the concept of internationalization was occurred and spread in the late 1960s; the trend of globalization emerged in the late 1980s. Particularly, the internationalization and globalization have different mission: the goal of globalization, establishing "universally-acknowledge" pattern beyond cultures and nations in opposite to the aim of internationalization, and focusing on communicating and exchanging within different countries and nations.

In the domain of complexity, the trend of globalization refers to the demographic variety, economic complexity, and cultural transformation. Specifically, from the cultural transformation perspective, the trend of globalization requires international students to solve multiple cultural problems by cognitive flexible, collaborative cooperation, and sophisticated interpersonal skills. Interdisciplinary reflections on the globalization also provide fundamental ways to deeply understand what is "mundane" in the anthropologist's domain. As a powerful vector of worldwide changes, globalization needs more effective dialogues in the multi-dimensional world. In addition, Castells (2000) defined "timeless time" and "space of flow" in accordance with the developing communication technology from politically neutral domain. Moreover, in the neo-liberal marketing world, policy divergences and policy convergences also dominate the legitimacy and integrity of the process of globalization worldwide (Bottery, 2000).

\section{Globalization and Higher Education Reform}

In the sphere of global economics, the diversification and reconstruction of higher education involve lots of pressures on higher education systems in global context. Particularly, Altbach (1991) suggested, "Despite its considerable durability as an institution, the modern university has, in recent years, been subjected to intense pressure to change, from government authorities, students, employers, professional associations and other external stakeholders" (p. 22). Johnstone (2000) also claimed that "the worldwide university reforms agenda raised from a sense of crisis facing higher education in countries as culturally and political diverse" (p. 24). In the neo-liberal education reforms, the financial crisis of higher education system has led to restructuring internal education systems. Moreover, in the pursuit of the neo-liberal reforms, public universities develop commercial activities for the purpose of commercialization of higher education globally. Moreover, what appears obviously is that neo-liberal market ideology focuses on providing guidance for restructuring of higher education system in global economic context. Additionally, Slaugther and Leslie (1997) discussed about the academic capitalism that "policy-makers in most English-speaking countries interpreted the real or imagined implications of the globalization for the restructuring of higher education in remarkably similar ways" (p. 54). As these results, emphasizing the concept of academic capitalism and global market trend, policy-makers pay much more attentions to enlarging the accountability of academic universities. Additionally, Currie and Newsom (1998) argued that "the global convergence of policies is an outcome of the structural conditions." And they also gave the definition that "a material set of practices drawn from the world of business." Associating with market ideology from neo-liberalism, policy-makers transform universities' systems into 
commercial entities. Moreover, Harvey (1989) also indicated that "an intense period of time space compression that has had a disorientating and disruptive impact on political-economic practices." In addition, Sassen (1991) discussed a set of attributes of economic globalization: "increasing economic transgression of national boundaries, improving capital mobility, and shifting from manufacturing to business and finance service, controlling economic activities." Furthermore, from a sociological perspective, Castells (2000) argued that "the social morphology of our societies, and the diffusion of networking logic substantially modifies the operation and outcomes in the processes of production, experience, power, and culture.” In this way, higher education is related in networking logic of contemporary capitalism globally. Generally speaking, from different logics of globalization, different epistemological and methodological assumptions have led to various reflections and rethinking towards the definitions of globalization. For example, not surprisingly, in the processes of economic globalization, Cox (1997) pointed out that globalization focused on decreasing forces that reduced policy options in the functionalist accounts of globalization. From a structuralism's perspective, "Globalization is a historical construct rather than a naturalized economic process operating in a reified fashion" (Soros, 1998, p. 29). Hence, the downsizing, deregulation, and privatization have occurred in the economic globalization world. Additionally, Bologna Declaration also indicated that the attributes of international trades in higher education concentrated on the competition and cooperation worldwide.

\section{Theoretical Framework}

\section{Neo-institutional Theory}

From a conceptual perspective, the neo-institutionalism concentrates on endogenous and exogenous forces shaping organizational dynamics and responses to changes. Specifically, the institutional theory contributes on "social constructs of rules, roles, norms, and the expectations that constrain individual and group choice and behavior" within organizations (Frederickson, 1999, p. 703). Hoffman (2001) argued that both internal and external forces were critical to analyze organizational and institutional changes. The neo-institutional theory sought to combine old and new institutionalisms to better understand the changes (Oliver, 1992). Actually, the modern institutional theory is rooted in two main streams: "Old institutionalism, focusing on intra-organizational dynamics or internal elements and new institutionalism, concerning on external factors and the concepts of legitimacy and isomorphism, defined as the processes by which organizations become homogenous in both process and structure over time" (e.g., Meyer \& Rowan, 1977, p. 12). Nevertheless, the social, cultural, political, and historical forces provide profound impacts on the development of organizations and institutions. Moreover, Spencer (1910) indicated that "society served as an organic system that evolved over time in relation to its particular context and around the concepts and structures of various institutions" (p. 145). Additionally, Scott (2001) defined that:

The concept defines the purposes or functions of the institution; the structure embodies the idea of the institution and furnishes the instrumentalities through which the idea is put into action. And institutions are both cursive, that is subject to social evolution, and enacted, or produced by rational intervention and intention. (p. 9)

Moreover, Weber (1924/1946) also summarized both internal and external forces influenced on institutional behaviors, concentrating on the legitimacy and authority in organizations. In another word, the endogenous and exogenous forces become the important components of the neo-institutional theory. In addition, sociological institutionalism has also merged in the public administrative theory in terms of the institutional 
theory. Generally speaking, the old institutionalism is associated with the public administration, including "authority relations, group dynamics, rationality and decision-making and connected with the role of organizational values and citizenship behaviors, and formalization and hierarchy" (Weber, 1924/1946, p. 38). Generally, "New institutionalism focuses on the impact of the wider institutional environment on organizations" (e.g., Meyer \& Rowan, 1977). More specifically, Scott (2001) also noted that "the transition from the 'old,' focusing on values, norms, rules, and other internal forces to the 'new,' focusing on external forces and organizational responses is one of the primary distinctions between old and new institutionalism" (p. 43). The neo-institutionalism generally contains both internal and external forces in terms of transitional changes in organizations and institutions. Oliver (1992) indicated, "Both internal and external forces play crucial roles in changing processes, and one must seek to understand elements of both if one is to understand the realities facing agencies" (p. 563). Similarly, Selznick (1996) suggested that there not existed distinct discrepancies between "new" and "old" institutionalism, but that different situations naturally focused on specific features of institutionalism. Greenwood and Hinings (1996) further argued that:

Typically, "new" institutional theorists have informed our thinking about the nature of institutional pressures toward conformity and uniformity. They emphasized the exogenous nature of change, which emanated from the realm of ideas and legitimacy. But understanding change was about understanding variations in response to the same pressures, which can only be done by analyzing the "internal" features of organizations that produce adoption and diffusion rather than resistance and inertia. (p. 42)

Historically, there are distinct discrepancies between old institutionalism and new institutionalism. Fundamentally, the old institutionalism can provide the institutional theory by analyzing internal factors to influence organizational processes; the new institutionalism is connected with economics, political science, and sociology.

From a historical perspective, the neo-institutional theory is associated with education, and many scholars have illustrated the relationship between neo-institutional theory and education in different domains. For example, Meyer (1977) wrote in The Effects of Education as an Institution, in his words, "move away from the contemporary view of educational organization as a production system constructing elaborated individuals" and instead to see the education "as a system of institutionalized rites transforming social roles through powerful initiation ceremonies and as an agent transforming society by creating new classes of personnel with new types of authoritative knowledge" (p. 56). Moreover, he further argued that education represented "a set of institutional rules which legitimately classify and authoritatively allocated individuals to positions in society and institutional impact of education on social structure itself - on the behavior of people throughout so" (Meyer, 1977, p. 59). More specifically, clarifying the internal and external factors is extremely important to China's higher education reforms. Combining organizational and environmental forces can be subjected to the interactional foundation of endogenous and exogenous factors for the holistic understanding of higher education reforms in current China. In addition, this research contributes to academically understanding the nature of interplay of endogenous and exogenous factors through the lens of neo-institutionalism concept. In the context of the fragmented and disarticulated Chinese higher education history, from 1953 to 2015, the institutionalism can provide a more distinct theoretical perspective to analyze the internal and external structure of higher education administrative and management reforms.

\section{Endogenous Forces: Decentralization (1953-1977)}

From the neo-institutional perspective, the trend of decentralization as an internal force is connected to the 
intra-organizational dynamics of China's higher education administrative system. Specifically, the internal organizational structure is subject to a tendency toward decentralized unified systems as social principles and changes. In the historical context, the transition from centralization to decentralization gradually took place from 1953 to 1962. In accordance with the political standpoint, shifted from the Soviet model to the Maoism model, the year of 1953 is characterized as an initial point of the centralization. Additionally, the First Five-Year Plan is closely associated with the Soviet model and implemented by the central government in higher education administration and management domains. Especially, in the higher education systems, the ownership of higher education system is established by the central government designed as a part of national plan. During China's First Five-Year Plan (1953-1957), in the higher education systems, the central government concentrated on "nationally unified teaching plans, syllabuses, materials, and textbooks were introduced for every academic specialty or major" (Pepper, 1990, p. 41). Additionally, the Chinese government also utilized and implemented the Soviet model and had a tendency to centralized higher education system in 1953. In another word, during the period of Great Leap Forward and the Cultural Revolution, Chinese education administrative systems had an obvious tendency toward developing decentralization.

From the historical context, the Great Leap Forward (1958) seemed to be a catalyst for the inception of decentralization. Specifically, Yang Xiufeng, the ex-president of the Ministry of Education (MOE), pointed out that "the existing institutional of higher education learning, finance system, leadership system, and the distribution of graduates too much emphasized on centralized and unified, which was the restriction on the enthusiasm and motivation from local higher education department" (Yang, 1987, p. 21). Indeed, the flexibility of internal education structure has led to more effective local administrative system and increased the number of students in regular higher education institutions (HEIs) and adult colleges. From 1957 to 1962, the number of students in regular HEIs was increased from 441,181 to 829,699 and the number of students in adult colleges was dramatically raised from 520,276 to $1,240,307$. So the year of 1960 was considered as the peak year both for the increased number of students in regular HEIs and adult colleges (see Figure 1).

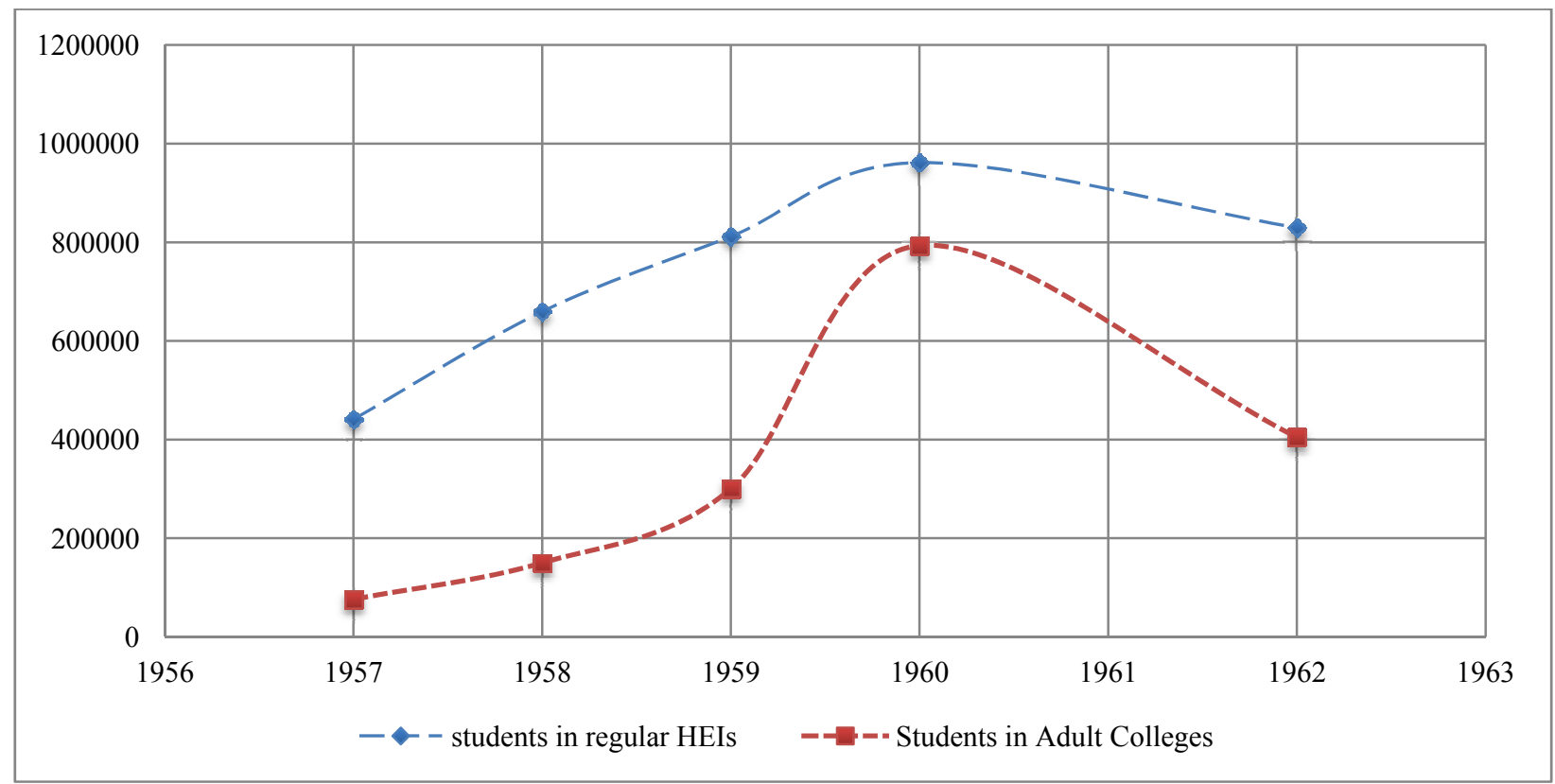

Figure 1. Number of students in HEIs (1957-1962) (Source: MOE, 1984). 
It is worth noting that the year of 1958 is the remarkable and profound turning point to decentralize higher education administrations and central authorities. In addition, the central government has still a tendency to decentralize higher education power and management, change vertical administrative model, and encourage regional education management. Particularly, in April 1958, the Central Committee released the Policy of Suggestions on Decentralizing Higher Institutions and Secondary Technical Schools, which covered the most of HEIs and secondary technical schools were belong to local provinces and autonomous administrative governments (MOE, 1984). And, a small number of universities or institutions still directly led by the MOE and central authorities. In response to this policy, the Central Committee also decided to decentralize and adjusted higher education enrollment system, graduation system, and employment allocation system. That meant local HEIs and secondary specialized colleges could recruit students on their specific timeline or schedule. In August 1958, the Central Committee released five decisions related to the power of higher education management and regulations, and these decisions pointed out that "strengthening local higher education management and leadership by state councils and empowering state councils to reasonably adjust national higher education regular, principles, and rules to suiting local different conditions in terms of locality" (Li, 2001).

Moreover, Pepper (1990) argued that during the movement of the Great Leap Forward (1958-1962), an unprecedented extension of mass education launched by Mao's policy of "walking on two legs" (p. 55). More specifically, the decentralizing administrative reforms in higher education systems also have stimulated the increased number of different types of HEIs. From 1957 to 1962, the number of comprehensive universities was increased by 610 , industry universities was increased by 206 , agricultural universities was increased by 69 , medical universities was increased by 118 , and normal universities was increased by 110 (see Table 1). Moreover, during the period of 1957 to 1962, the number of HEIs was increased from 206 to 407 and the year of 1960 was still considered as the peak year with HEIs of 1,289 (see Figure 2). However, the enlarging scales' process of decentralization of education has led to the poor quality of higher education. Specifically, during the historical period of Great Cultural Revolution (1966-1976), stimulating from the overwhelming movement of Superstructure Revolution, China gradually implemented decentralizing higher education. In fact, the Great Cultural Revolution dismantled all the traditional higher education systems, including curriculum, administration, and teacher education. To this extend, the movement of Great Cultural Revolution provides a pivotal vehicle to develop the trend of decentralization in China. Moreover, the China Central Committee published the Report of Improving Universities Recruitment, indicating that shifting the central universities recruitments to local and autonomous regions, and released the announcement on Revolution of Universities Recruitment and Admission, which concentrated on transitions of recruitment's power from central to local. Additionally, in August 1971, Summaries on National Education Meetings pointed out that local governments should give priority to cultivating leadership to manage local colleges and universities (Zhou, 2000). In the Chinese contextual background, the shifting from centralization to decentralization occurred relatively in the process of education reforms and these transitions initiated by the central government with the absolute education ownership and funding resources. In response to the policies of "bring order out of chaos," in 1977, the central government emphasized on the centralization of management to recover central-oriented leadership and power. 
Table 1

The Number of Classified HEIs

\begin{tabular}{rrllllllll}
\hline Year & Total & $\begin{array}{l}\text { Comprehensive } \\
\text { universities }\end{array}$ & $\begin{array}{l}\text { Industry } \\
\text { universities }\end{array}$ & $\begin{array}{l}\text { Agricultural } \\
\text { universities }\end{array}$ & $\begin{array}{l}\text { Medical } \\
\text { universities }\end{array}$ & $\begin{array}{l}\text { Normal } \\
\text { universities }\end{array}$ & $\begin{array}{l}\text { Finance } \\
\text { colleges }\end{array}$ & $\begin{array}{l}\text { Law } \\
\text { schools }\end{array}$ & Others \\
\hline 1957 & 229 & 17 & 44 & 28 & 37 & 58 & 5 & 5 & 35 \\
1958 & 791 & 27 & 251 & 96 & 134 & 171 & 12 & 5 & 95 \\
1960 & 1,289 & 37 & 472 & 180 & 204 & 227 & 25 & 9 & 135 \\
1962 & 610 & 31 & 206 & 69 & 118 & 110 & 17 & 3 & 47 \\
\hline
\end{tabular}

Note. Source: MOE (1984).

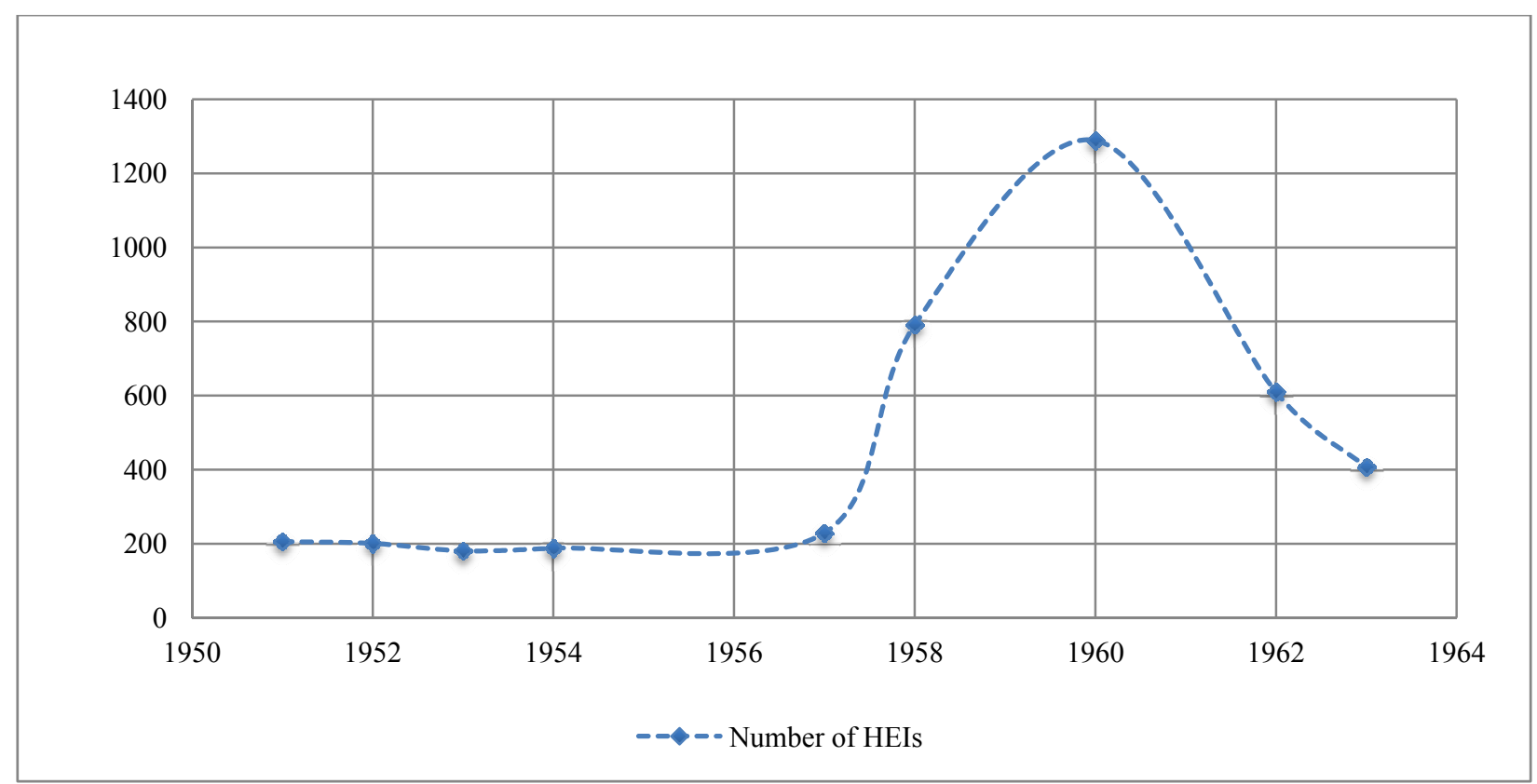

Figure 2. The number of HEIs (1952-1963) (Source: MOE, 1984, pp. 975-977).

\section{Exogenous Forces: Globalization (1978-1999)}

From the neo-institutional perspective, the rend of globalization is characterized as an external force, which is incentive to internal institutional changes in the China's higher education administrative context. Profoundly, the trend of globalization is intangibly hidden behind the trend of so-called "socialist modernization" and "socialist market economy." Practically, the causal relationship between occurrences of globalization and "socialist market economy" is mainly clarified by the macroscopic causality in the social science domain. In another word, globalization serves as exogenous forces, which can evoke the internal organizational pressures and changes in China's economic and political society. As this result, socialist modernization and socialist market economy can be considered as external approaches to alleviate the internal organizational pressures and changes in the higher education administrative systems. In response to the urgent demands of rapid development of socialist modernization and socialist market economy, the refresh stream of globalization has led to profound insightful changes and pressures to China's higher education system.

In the late 1970s, the Opening Policy (1978) made a tremendous influence in the development of globalization. Since 1978, the decentralization from Western education plays a dominated role in disseminating the concept of globalization. Moreover, Western education is subjected to high decentralized, with opposite to 
the Soviet model that was more characterized as central controlled. Hence, it becomes more controversial to evaluate the performance and outcome of China's higher education whether or not made thoroughly transitions from the Soviet model to the Western model. The Chinese government has gradually implemented higher educational administrative reforms in accordance with the comprehensive constructional and decentralized administrative influences from Cultural Revolution. In the 1980s, in order to mitigate enrollment bias, which students studying in finance, economics, law, and business management occupied a small proportion, the Chinese government made an adjustment in curriculum, expanding the enrollments for these majors and adding interdisciplinary majors in science and technology. Since 1980, in order to consolidate regular higher education, the central government integrated short-cycle colleges, non-degree colleges, and vocational and technical colleges. In 1984, the Central Committee released the Decision on Education System Reform, which concentrated on changing traditional education administration and management to accompany with the global economic trend. This decision was specifically related to ensuring and enlarging universities' autonomy under the unified educational principles and guidelines. In 1985, the Central Committee of the Chinese Communist Party (CCP) launched the Decision on Reform of Education System, concerning on carrying out Chinese educational reforms. Accounting for realizing China's socialist modernization, since 1985, higher educational system reforms were gradually initiated by the Chinese government. The CCP's 14th Congress (1986) established the socialist market economy, which was endorsed as a goal of the economic reform (Kwong, 2000). Hawkins (1983) suggested that in order to improve the enrollment rates of Chinese higher education, since 1988, the Chinese government has implemented "two tracks" system, concerning on universities or colleges received tuition fees and should be responsible for employments. Since 1992, the market-oriented economy has gradually generated in social and educational reforms, associating with approving universities or colleges to enroll up to $25 \%$ students in "commissioned training" or "fee-paying" categories. The development of globalization concentrates on the cultural assimilation of Westernization ideology. Robertson (1992) argued that "globalization as a concept refers both to the compression of the world and the intensification of consciousness of the world as a whole" (p. 123). Learning from the advanced Western concepts and ideas can provide multiple channels for Chinese to broaden international insight and enriching social activities. During post-Mao period, the central government has implemented to restore and duplicate original and traditional ideas, which have contributed to guaranteeing its leading authority. It was not surprising that the regulations and standards, concerning on keeping high quality of allocating educational resource, were offered by the central government. Moreover, Qiang (1996) argued, "Education reform was performed with a trait of high decentralization" (p. 17). In 1988, Li Peng, in the National Education Meetings, suggested that "the mission of higher education reform is to gradually cultivate effective mechanisms to adapt national economic growth and social development" (Li, 1988). In 1989, the National Education Committee released relevant documents to clarify that "the core of higher education system reform is to accessible and adaptable mechanisms in consistence with commodity economy" (National Education Committee, 1989). During that period, China's higher education reforms were definitely followed by economic mechanism reforms and political mechanism changes.

The central government has gradually designed and implemented a bunch of higher education policies, concerning on the globalization of China's higher education systems. Specifically, "Southern Talk" by Deng Xiaoping can be regarded as the significant landmark to build the socialist modernization and socialist market economy. In response to adapting the new policy, two documents, Suggestions on Enhancing and Developing 
Higher Education and Outlines of China's Education Development and Reform are completely emphasized on the reforms of the higher educational administrative systems. In 1993, the Central Committee and State Council released China's Education Reform and Development Outline, basically concerning on "building new education system in accordance with political and technical reforms." Additionally, The National Education Law of the People's Republic of China explicitly clarified that "the State Council and local governments, based on principles of classification management, and various division of responsibilities manage education works" (China Education Review, 1949). Indeed, it is difficult to shift from aggregation to segregation substantially. Moreover, in 1997, the 15th National People's Congress (NPC) more emphasized on higher education reforms, which suggested to optimize the higher education structure, accelerate the paces of higher educational administration and management system reforms, improve higher education quality, and rational allocate higher educational resources. In response to the 15th NPC, in 1998, Li Lanqing, the ex-vice president of the national council, in the Meeting of the Higher Education System Reforms, further emphasized on intensifying the comprehensive higher education reforms. In 1999, following the five reforms keywords: "coordination," "co-construction," "combination," "collaboration," and "transformation," the central government basically completed institutional and system transitions with the remarkable achievements of HEIs and universities. Since December 2000, Chen Zhili, the ex-president of the MOE, indicated that "we should consistently deepen the higher educational administrative reforms, accelerate provincial level universities' reforms and optimize higher educational structures" (Chen, 2000, p. 21). Furthermore, Li (2001) concluded that, since 1992, the higher education system reforms obtained tremendous achievements. Specifically, throughout eight years, 31 provinces, cities, and autonomous regional local governments worked along with about 60 departments affiliated by national council were involved in about 900 institutions and universities. According to the statistics from Li (2001), the number of regular institutions reduced from 1,080 in 1994 to 1,018 in 1999; the number of adult colleges rapidly decreased from 1,321 in 1990 to 811 in 1992. Combing and merging of the HEIs, the central government has established a bunch of comprehensive and multi-disciplinary universities to guarantee the effectiveness of higher educational structures and systems. Moreover, the central government directly subordinated adults' colleges, which were decreased from 281 in the peak of 1995 to 55 in the year of 2001. By the virtue of raising local economic construction and social development, cultivating central and provincial education administrative systems would lead to the dual management structures in China's higher education system. From 1996 to 1999 , accounting for keeping paces with the changes of labor market, the Chinese government enlarged the percent of enrollments of students, majoring in literature, engineering, medicine, and law, discarded the percent of enrollments of student with non-degree programs in response to the main function of the National Entrance Examination, which contributed to keeping the high quality of tertiary education. There also existed some critical considerations on the evaluative assessment, equal enrollment opportunities, and validation of the standardization in China's higher education themes. In order to alleviate the drawbacks and disadvantages of the National Entrance Examination, since 1984, Shanghai initially has introduced a series of experimental programs to mitigate disadvantages of the entrance examinations. In 1999, a new policy, focused on selecting individual preferences of HEIs or majors after releasing scores of entrance examinations, provided more and more rational choices instead of inaccurate estimation of scores. This policy also trigged the expansion of the number of short-cycle vocational colleges. From 1999 to 2001, the number of short-cycle vocational colleges was increased from 161 to 386 compared with the number of universities and vocational colleges (see Table 2). 
Table 2

The Number of Regular HEIs (1999-2001)

\begin{tabular}{|c|c|c|c|c|}
\hline Year & Total & Universities and colleges & Vocational colleges & Short-cycle vocational colleges \\
\hline 1999 & 1,071 & 597 & 313 & 161 \\
\hline 2000 & 1,041 & 599 & 258 & 184 \\
\hline 2001 & 1,225 & 597 & 242 & 386 \\
\hline
\end{tabular}

Note. Source: MOE (2014).

\section{The Interplay of Globalization and Decentralization (2000-2015)}

In the neo-institutional concept, the interplay between the decentralization as an internal force and the globalization as an external force is critical to analyze the organizational and institutional changes in China's higher educational administrative context. Essentially, the neo-institutionalism significantly concentrates on endogenous and exogenous forces shaping the organizational dynamics and responses to the changes in different contextual backgrounds. Specifically, both the decentralization as the internal force and globalization as the external force cultivate the intercommunicating, interacting, and interconnecting approaches to reconstruct China's higher education administrate categories in the contextual background. More specifically, from 1999 to 2001, the regular HEIs were typical divided into three main types of administrative institutions: universities and colleges, vocational colleges, and short-cycle vocational colleges (see Table 2). Moreover, both enrollment rates and scales of HEIs are rapidly raised in response to the reconstruction of higher education administrate classifications. Particularly, from 1991 to 2014, the gross enrollment rate of higher education was dramatically increased from 3.5\% in 1991 to $37.5 \%$ in 2014 (see Figure 3). Additionally, the average size of regular HEIs, from 1994 to 2014, was increased from 2,591 to 7,704 (see Figure 4).

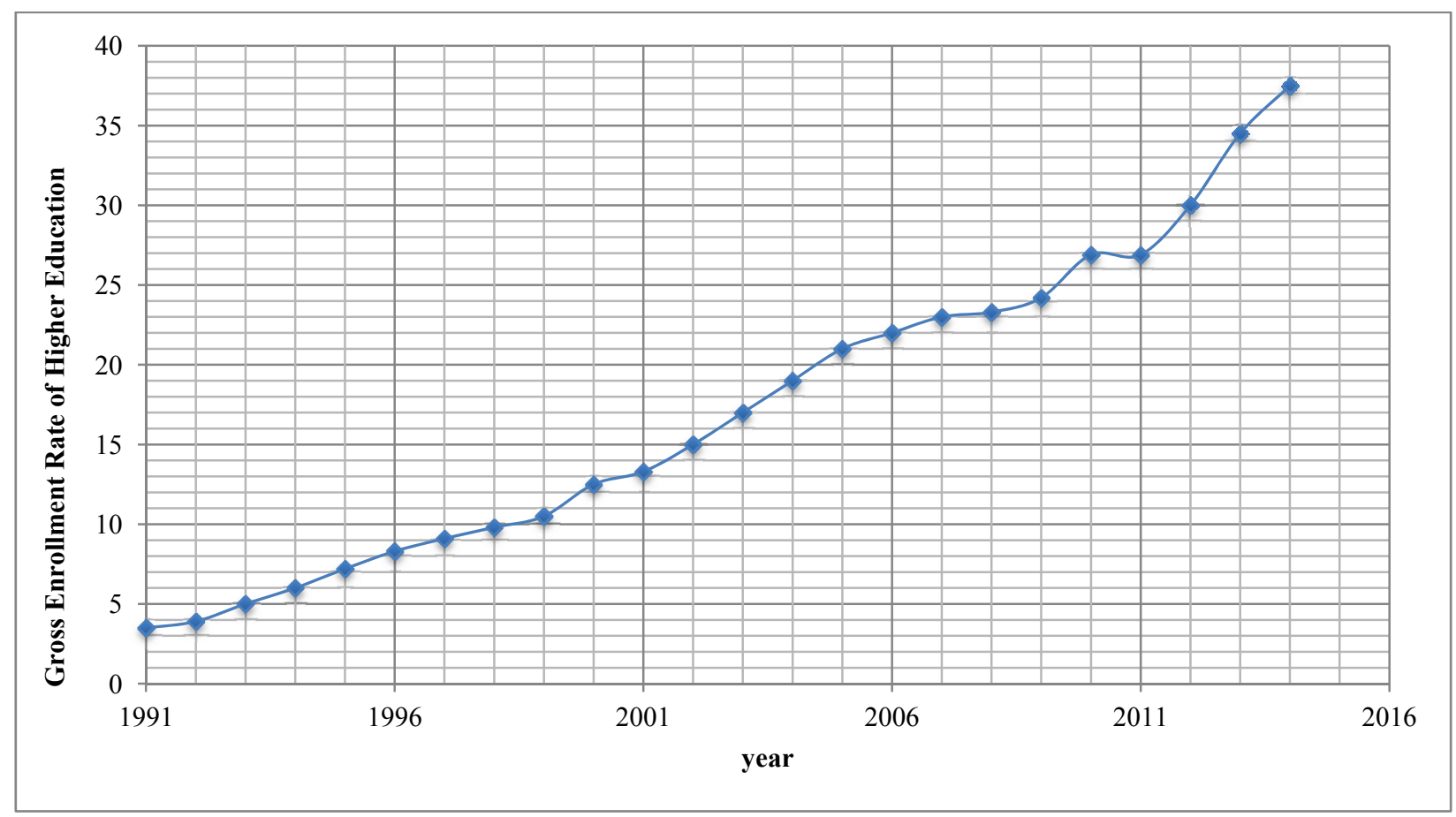

Figure 3. Gross enrollment rate of higher education (1991-2014). 


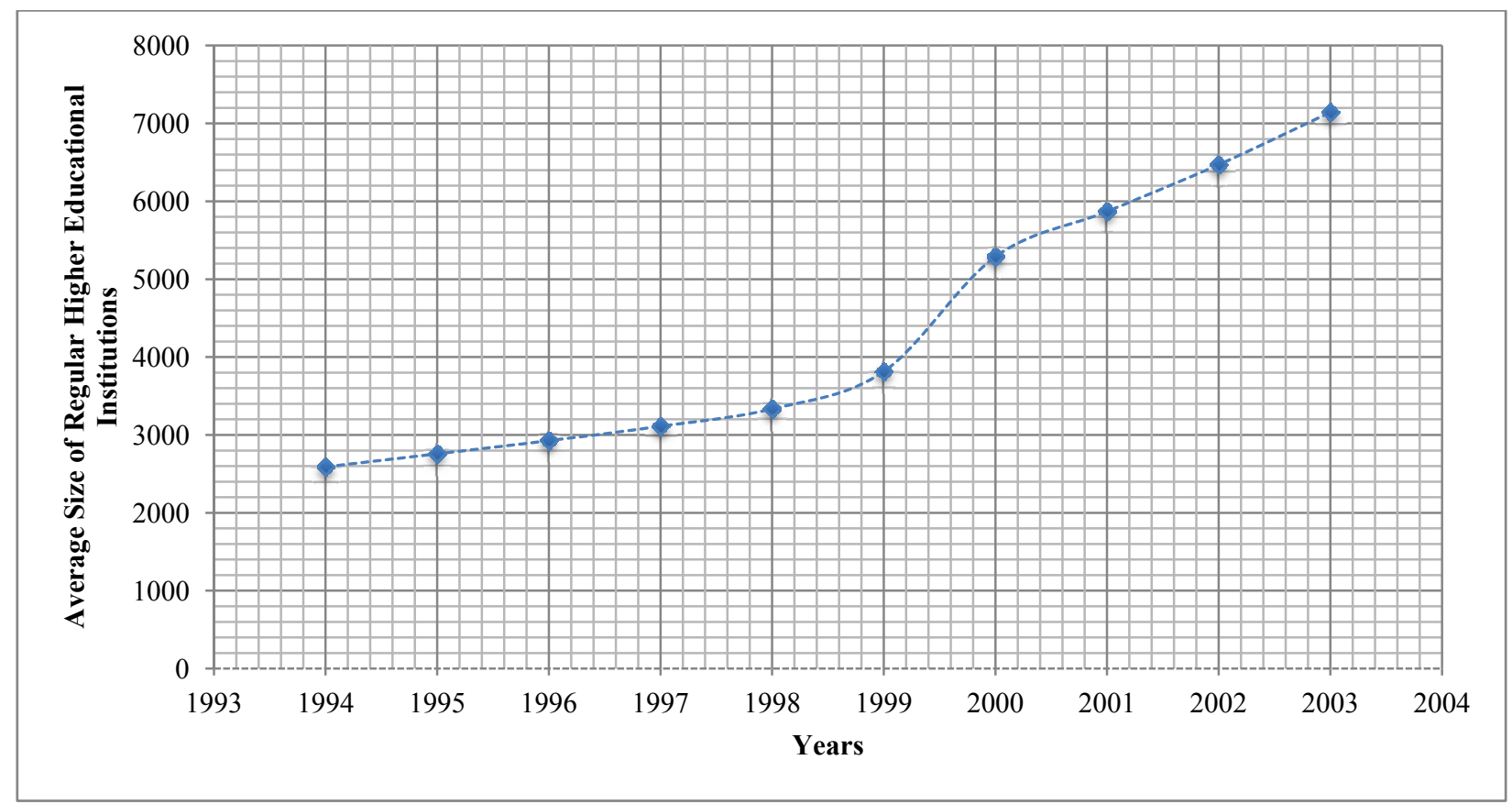

Figure 4. Average size of regular HIEs (1994-2014).

\section{Private Higher Education}

In contemporary China, the emergence of private higher education demonstrates the functions of the interplay between globalization and decentralization in China's higher education systems. The proliferation of China's private higher education reshapes and reconstructs the landscapes of contemporary higher education systems. Moreover, private higher education in current China, concerning on the combination of academic-oriented and market-oriented, can continuously provide the occupational and professional skills to the labor market. However, the controversial debates involve in striking echoes in the highlighted context of China's higher education systems. Historically, Confucius as an initial private educator (551-479 B.C.) established China's private schools and developed the prosperity and diversification of private schools. The traditional private education focuses on the literacy and numeracy in secondary education. The coexistence of private and public education has lasted for 2,000 years in China's traditional education systems. In modern social context, in 1980s, the Opening Policy was embarked on establishing private education to promote the internal decentralizing higher education. Moreover, in recent decades, the flourishing global economics stimulates the development of China's private higher education in external global environment.

The expansion of private HEIs witnesses the rapid growth of social demands of private higher education. Specifically, in the higher education realm, the private education refers to the schools, colleges, and institutions, operated and arranged by non-government organizations, or private groups of self-funding supports. In addition, Wang Jiaqiu, the former vice-president of the NPC, gave the official explanations of private higher education: "The ownership, resources of funding, target customers and the contents of service served as main characteristics of defining China's private higher education" (Wang, 1997, p. 11). Moreover, the central government authorized and released the Law of Promotion for Private Education in 2002 and the private higher education served as independent colleges with self-funding allocation. In 2003, Zhou Ji, the ex-president of the MOE, suggested that "massification of higher education was the mainstream of the development of higher 
education" (Zhou, 2004, p. 21). More specifically, from 2002 to 2013, the total number of regular HEIs was increased from 1,396 to 2,529. From the administrative perspective, from 2002 to 2014, there existed three main types of higher education administration system, which included HEIs under central ministries and agencies, HEIs under local authorities, and non-state private colleges. Both the number of HEIs under MOE and HEIs under central agencies kept stable. However, the number of HEIs ran by higher education departments and non-education departments grew dramatically. More remarkably, since 2012, the number of non-state private colleges rapidly increased by 727 (see Table 3).

Table 3

The Number of Regular HEIs (2002-2013)

\begin{tabular}{|c|c|c|c|c|c|c|c|}
\hline \multirow[b]{2}{*}{ Years } & \multirow[b]{2}{*}{ Total } & \multicolumn{2}{|c|}{$\begin{array}{l}\text { HEIs under central ministries and } \\
\text { agencies }\end{array}$} & \multicolumn{2}{|c|}{ HEIs under local authorities } & \multirow{2}{*}{\multicolumn{2}{|c|}{ Non-state private }} \\
\hline & & HEIs under MOE & $\begin{array}{l}\text { HEIs under } \\
\text { other central } \\
\text { agencies }\end{array}$ & $\begin{array}{l}\text { Run by education } \\
\text { departments }\end{array}$ & $\begin{array}{l}\text { Run by } \\
\text { non-education } \\
\text { departments }\end{array}$ & & \\
\hline 2002 & 1,396 & 72 & 39 & 776 & 378 & 131 & \\
\hline 2003 & 1,552 & 73 & 38 & 767 & 501 & 173 & \\
\hline 2004 & 1,731 & 73 & 38 & 799 & 595 & 1,187 & \\
\hline 2005 & 1,792 & - & - & - & - & - & \\
\hline 2006 & 1,867 & 73 & 38 & 853 & 627 & 276 & \\
\hline 2007 & 1,908 & 73 & 38 & 852 & 650 & 295 & \\
\hline 2008 & 2,263 & 73 & 38 & 859 & 655 & 638 & \\
\hline 2009 & 2,305 & 73 & 38 & 877 & 661 & 656 & \\
\hline 2010 & 2,358 & 73 & 38 & 854 & 719 & 674 & \\
\hline \multirow[t]{2}{*}{2011} & 2,409 & 73 & 38 & 969 & 583 & 696 & \\
\hline & & & & & & \multicolumn{2}{|c|}{ Local enterprises } \\
\hline 2012 & 2,442 & 73 & 38 & 967 & 604 & 52 & 706 \\
\hline 2013 & 2,491 & 73 & 40 & 1,015 & 598 & 48 & 717 \\
\hline 2014 & 2,529 & 73 & 40 & 1,053 & 592 & 44 & 727 \\
\hline
\end{tabular}

Note. Source: MOE (2014).

The development of private higher education is associated with policies, economics, and cultures. Additionally, the expansion of private higher education is rooted in the social transitions in terms of the Opening Policy. Moreover, Geiger (1986) argued that "there were three main categories to describe private education: mass, parallel, and peripheral private sectors" (p. 34). In response to economic and social political environments, China's private education has in an ambiguous position in contemporary higher education systems. Moreover, Min (1999) also pointed that "China' private education was characterized by the gradual social and economic transitions from ossified, centrally planned system to the dynamic, socialist economics." Indeed, the profound social and economic transitions trigged a series of challenges of higher education reforms. In response to transitions of higher education administration, it is difficult to integrate the decentralization as internal intra-organizational force and globalization as external environmental force. However, the autonomy and flexibility of private higher education can provide local communities and non-state units more opportunities to involve in higher educational administration and management. Particularly, Hanson (1998) also suggested that "decentralization refers to the transfer of decision-making authority, responsibility, and tasks from higher to lower organizational levels or between organizations" (p. 112). Moreover, in 1995, the 
Education Law (MOE, 1995) illustrated that non-government sectors or units also have qualified and legitimated to run private colleges and universities. Additionally, in 1998, the Higher Education Law (MOE, 1998) further pointed out that higher education should be characterized as diversified higher education. In 2002, the Law of Promotion for Private Education was regarded as the first national legislation to facilitate private higher education. Additionally, the administrative autonomy has been allowed to independently establish relevant policies of enrollment, funding, and international cooperation. Specifically, the private higher education is currently categorized into these types: regular HEIs, higher vocational education colleges, self-taught and self-studied programs, professional qualification certificates programs, and Sino-foreign jointly funded colleges. Moreover, independent colleges represent a remarkable landmark in China's private higher education systems. In 1999, some coastal provinces, such as Zhejiang and Jiangsu, also occurred state-owned or non-government secondary colleges and shown the promising prototypes of independent colleges.

The challenges and opportunities for China's private higher education are interdependent in current higher education systems. Particularly, in order to meet the demands of the accessible higher education, the private higher education has developed the non-government financial and administrative systems. The trend of globalization of higher education can be a catalyst for cultivating private higher education when China joined the World Trade Organization (WTO) in 2001. Moreover, the private higher education provided the autonomy and accountability to China's higher education systems in the administration and management fields. Undoubtedly, the sufficient authority was considered as a crucial factor to formulate and implement private higher education. Additionally, Levy (2009) summarized three types of global private higher education, including elite/semi-elite, religious/cultural, and non-elite/demand-absorbing. Specifically, China's private higher education is attributed to the type of non-elite/demand-absorbing. Faced with the political and institutional environments, the private higher education is deliberately encouraged by China's central government to meet demands of accessibility of higher education. In another word, the dissemination of the private higher education serves as one vehicle to cultivate organizational diversity in the higher education system. Moreover, the private education has isomorphic tendencies to the market competitions and market-oriented systems. The prosperous private higher education has been regarded as private-owned institutions. Additionally, Di Gropello (1999) identified three categories of institutional isomorphism, namely, coercive, mimetic, and normative. The notion of institutional isomorphism stresses the importance of legitimacy and the logic of appropriateness for processes of homogenization. Meanwhile, the market niches have created a new form of private higher education. For example, public and private partnership colleges were named as independent colleges.

\section{Cost-Sharing Reform}

In accordance with the globalization and decentralization in current China's higher education systems, the most prominent barriers, which encounter China's higher education, are the complex structural mechanism and affordability of HEIs. In the past three decades, shifting from government fund-oriented to cost-sharing marketing system had emerged in the rapid global economic growth, concerning on increasing the demands of higher education and effective state budgetary policies. The cost-sharing reform of tertiary education is characterized as one prominent achievement of the fundamental outcome of the interplay of globalization and decentralization. The cost-sharing reform has also aroused a series of fierce discussions on the pressures of higher education, accounting for the educational resource shortage, finance elimination, and internal or external competitions. Specifically, some scholars argued that such market-oriented education reforms would lose 
"pedagogical nature of higher education." When the central government shifted the power to the local governments, the pressures of the human resource shortage, financial support elimination, and internal competition can prevent the development of decentralization and globalization in higher education systems. Ding (2000) also argued that "the knowledge-driven and technology-intensive economy pushed more pressures to the central government to practically develop more effective professional strategies toward new trends of globalization." Since the 1990s, the expansion of higher education enrollment has simulated serious pressures on current China society. In the educational market, especially in the international education market, private HEIs need more opportunities to compete with other foreign institutions (Shen, 1997, p. 93).

A bunch of higher education policies have been completely implemented to incentive the development of cost-sharing process. In accordance with the cost-sharing reform of tertiary education in current China, the central government makes transitions from free higher education to cost-sharing higher education financing system. Particularly, Wing-Wah (1995) summarized and divided different periods of implementing cost-sharing process: in 1952-1970s, higher education, in "people's Grant" period, was completely funded by the central government in State-Planned Enrollment Policy; during the mid-1970s and 1984, increasing enrollment, declining central government funds, increasing demands of higher education, and limiting the people's Grants were considered as the mainstreams of higher education financing patterns. In 1983-1988, three admissions subjects, including state-planned enrollment, contracted enrollment, and fee-paying enrollment, were adopted and the people's Grant was abolished. In addition, the student loans and scholarships were adopted by the central government. From 1989 to1993, state-planned enrollment, contracted enrollment, and fee-paying enrollment were served as three main schemes. Generally, the increasing number of higher education enrollment has shown the dramatic changes and trends from free higher education to cost-sharing higher education financing system. Particularly, the higher education enrollments carve has vividly described this trend: from 1994 to 1997, the regional economic development, individual affordability, and social economic statuses had been considered to charge actual tuition fees with keeping rising annual growth rate of about $19 \%$ averagely from 1990 to 1997. In addition, during 1998 to 2015, the gross enrollment increased from 9.8\% in 1998 to about $26 \%$ in 2015.

Nevertheless, the accountability and affordability have fundamentally dominated the quality and effectiveness of higher education reforms. Particularly, according to the statistics, from January 2011 to November 2011, the national public finance budget spending on higher education reached to 12,332 billion, increased by $25.8 \%$ than the same period in 2010. In 2011, the central fiscal expenditure on education is expected to 3,259 billion, rising to $27.8 \%$ in 2010 ( $\mathrm{Liu}, 2012$ ). Moreover, increasing the fiscal expenditure on the education provides fundamental support for the development of educational career. In 2012, Education Informatization Development Plan for Ten Years (2011-2020) (MOE, 2012) indicated to strengthen the construction of the digital campuses and applications, build digital the research collaboration supporting platform and educational informative network infrastructure, promote research and experimental bases, scientific instruments, natural science and technology resources, scientific data sharing, and support interdisciplinary, collaborative innovations across regional and national boundaries.

In order to deal with the dual pressures and changes from the interplay of globalization as an external force and decentralization as an internal force, a series of educational reforms' plans have implemented to fulfill constructing human resource power and innovative society in current China's higher education scene. Specifically, Education Revitalization Plan (2003-2007), concentrated on continuing to implement the "985" 
Project and "211" Project, strives to build high levels universities, strengthen the implementation of high level creative outstanding person programs, and promote the graduate students' educational innovation plans. Additionally, the mission of The National Mid-long Term Education Development Planning (2010-2020) is subjected to cultivating educational talents, who served as the crucial resources and strategic positions in constructing human resource power and innovative society. For higher education, these plans have focused on cultivating and accumulating leading talents with the international academic influences, fostering the youth academic outstanding persons, and strengthening the management of higher education personal. Moreover, Yuan Guiren, the current president of the MOE, indicated in 2012 National Education Conference that building new mechanisms, exploring and establishing collaborative innovative systems, further breaking institutional barriers between universities and institutions, and promoting the quality of higher education should be considered as significant tasks for China's higher education reforms currently (Yuan, 2012).

\section{Findings and Conclusions}

This article through the lens of neo-institutional dimension concentrates on internal, external, and interplay forces, which are guiding and directing the trends of China's higher education administration and management reforms. Specifically, decentralization as an internal force is connected to intra-organizational structures of China's higher education administrative system, and globalization as an external force is an incentive to internal institutional changes in China's higher education administrative context. The interplay of decentralization and globalization is critical to analyze organizational and institutional changes in contemporary China's higher education systems.

From the macro scope of China's higher education management and administration reforms, it mainly concentrates on three dimensions: coordinating the relationship between central and local dual administrative power; enlarging provincial autonomy and decision-making power of higher education administration; and expanding the autonomy of universities and institutions. From a historical perspective, decentralizing higher education administration system, concerning on the shifting from "centralizing" to "decentralizing," objectively, smashed the original internal rampart of China's traditional higher education administration systems. Additionally, decentralizing administrative power has led to provide effective management approaches and connect the labor market demands and professional training. For example, in order to adapt to developing socialist market economy as external forces, the "211" project has led to the transitions of higher education system reforms and school running ideas. The multiple patterns among central-department, central-local, and department-local motivate higher education internal administration reform currently.

The interplay of decentralization and globalization in China's higher educational financial and administrative contexts has provided the rational allocation of limited educational resources and decentralizing administrative authorities. Specifically, from a social political perspective, the antagonistic relations between macro-adjustment and free-market demand may not lead to a reasonable higher education structural system. Moreover, China's central government has a tendency toward the decentralization in historical context of social changes. Combining macro-plan and micro-professionalism provides a significant pathway for the present China as well as the future China (Xu, 2005, p. 94). Additionally, from a legislator perspective, China's higher education as a legislative entity has responsibilities to cooperate and communicate with foreign universities. And China's higher education reforms are considered as multi-dimensional agendas. Devolving the power and responsibility to local governments serves as first steps in the higher education decentralization and localization 
reforms by the MOE. For instance, the provincial or municipal governments can reconstruct and supervise local colleges under provincial authorities and power. Broadly speaking, coordinating the relationships between central and local dual administrative powers, enlarging provincial autonomy and decision-making power of higher education administration, expanding the autonomy of universities and institutions are considered as rational and effective pathways to deal with the globalization and decentralization forces in higher education administrative and management reforms contemporarily.

\section{References}

Ainley, J., \& McKenzie, P. (2000). School governance: Research on educational and management issues. International Education Journal, 1(3), 139-150.

Altbach, P. (1991). Patterns in higher education development. Prospects, 21(2).

Ayyar, R. V. V. (1996). Educational policy planning and globalization. International Journal of Educational Development, 16(4), 347-353.

Blackmore, J. (2000). Globalization: A useful concept for feminists rethinking theory and strategies in education? In N. C. Burbules, \& C. A. Torres (Eds.), Globalization and education: Critical issues. London, U.K.: Routledge.

Bottery, M. (2000). Education, policy and ethics. London, U.K.: Continuum.

Castells, M. (2000). Material for an exploratory theory of the network society. British Journal of Sociology, 51(1), 5-24.

Central Committee and State Council. (1993). China's education reform and development outline. Beijing: China Education Press.

Chen, Z. L. (2000, December 23). 15th education interview. Guang Ming Daily Newspaper, p. 1.

China Education Review. (1949). China Macropaedia Press.

Cox, K. (1997). Spaces of globalization. New York, N.Y.: Guidford Press.

Crossley, M. (2000). Bridging cultures and tradition in the reconceptualization of comparative and international education. Comparative Education, 36, 319-332.

Currie, J., \& Newsom, J. (1998). Universities and globalization: Critical perspectives. Thousand Oaks, C.A.: Sage Publications.

Deng, X. P. (1994). Selected works of Deng Xiaoping (Vol. 2). Beijing: People's Publishing House.

Department of Higher Education. (2000). The reform and construction on higher vocational education: Selected documents of higher vocational education in 1999 (Vol. 1, pp. 118-119). Beijing: Higher Education Press.

Di Gropello, E. (1999). Los modelos de descentralizacióneducativa en América Latina (Educational decentralization models in Latin America). Revista de la Cepal, 68, 153-170.

Ding, G. (2001). Teacher education in China-Introduction. In G. Ding (Ed.), Symposium: Teacher education and development in China. Hong Kong: The Hong Kong Institute of Education.

Du, H. (2001). The globalization of the English language: Reflections on the teaching of English in China. International Education Journal, 2(4), 126-133.

Dworkin, A. G. (2001). Perspectives on teacher burnout and school reform. International Education Journal, 2(2), 69-81.

Frederickson, H. G. (1999). The repositioning of American public administration theory primer. Boulder, C.O.: Westview Press.

Geiger, R. L. (1986). Private sectors in higher education: Structure, function, and change in eight countries. Ann Arbor, M.I.: The University of Michigan Press.

Gibson-Graham, J. K. (2006). The end of capitalism (As we know it): A feminist critique of political economy, with a new introduction. Minneapolis, M.N.: University of Minnesota Press.

Greenwood, R., \& Hinings, C. R. (1996). Understanding radical organizational change: Bringing together the old and the new institutionalism. The Academy of Management Review, 21(4), 1022-1054.

Hanson, M. E. (1998). Strategies of educational decentralization: Key questions and core issues. Journal of Educational Administration, 36(2), 111-128.

Harvey, D. (1989). The condition of postmodernity. Oxford, U.K.: Blackwell Publishers.

Hawkins, J. N. (1983). Education and social change in the People's Republic of China. New York, N.Y.: Praeger Publishers.

Hoffman, A. J. (2001). Linking organizational and field-level analyses: The diffusion of corporate environmental practice. Organization Environment, 14(2), 133-156.

Johnstone, D. B. (2000). Worldwide reforms in the financing and management of higher education. Washington, D.C.: The World Bank. 
Kenway, J. (1997). Education in the age of uncertainty: An eagles' eye view. South Australia: Mimeo.

Knight, J. (2002). The impact of GATS and trade liberalization on higher education. In Globalization and the market in higher education: Quality, accreditation and qualifications (pp. 191-209). Paris: UNESCO.

Knight, J. (2003). Interview with Jane Knight. IMHE Info, 1, 2.

Kwong, J. (1996). The new educational mandate in China: Running schools running businesses. International Journal of Educational Development, 16, 185-194.

Kwong, J. (2000). Introduction: Marketization and privatization in education. International Journal of Educational Development, 20, 87-92.

Lan, Y. (1996). A review of teacher professorate movement in U.S.. Foreign Country Education Study, 4, 42-46.

Levy, D. C. (2009). Chapter 1: Growth and typology. In S. Bjarnason, K. M. Cheng, J. Fielden, M. J. Lemaitre, D. Levy, \& N. V. Varghese (Eds.), A new dynamic: 19 private higher education (pp. 7-28). Paris: UNESCO.

Li, P. (1988). Speech at the National Education Committee meetings. Beijing: China Education Press.

Li, D. (1999). Modernization and teacher education in China. Teaching and Teacher Education, 15, 179-192.

Li, Q. G. (2001). On the evolution of China's higher education administrative system reforms since the founding of the PRC. Contemporary China History Studies, 8(3), 55-63.

Lin, Q., \& Xun, Y. (2001). The institutional and policy development of teacher education in China. Asia-Pacific Journal of Teacher Education \& Development, 4(2), 5-24.

Lingard, B. (2000). It is and it isn't: Vernacular globalization, educational policy, and restructuring. In N. C. Burbules, \& C. A. Torres (Eds.), Globalization and education: Critical issues. London, U.K.: Routledge.

Liu, Y. D. (2012). The speech on 2012 National Education Conference. Beijing: China Education Press.

Marrow, R. A., \& Torres, C. A. (2000). The state, globalization, and education policy. In N. C. Burbules, \& C. A. Torres (Eds.), Globalization and education: Critical issues. London, U.K.: Routledge.

McGuire, J., \& Mauro, C. (1997). Rethinking development: Concept, policies, and contexts. Los Angeles, C.A.: University of Southern California.

Meyer, J. (1977). The effects of education as an institution. The American Journal of Sociology, 83(1), 53-77.

Meyer, J. W., David, J. F., Ann, H., Evan, S., \& Nancy, B. T. (1997). The structuring of a world environmental regime, 1870-1990. International Organization, 51(4), 623-651.

Meyer, J., \& Rowan, B. (1977). Institutionalized organizations: Formal structure as myth and ceremony. The American Journal of Sociology, 83(2), 340-63.

Meyer, J., \& Scott, W. R. (1983). Centralization and the legitimacy problems of local government. In J. W. Meyer, \& W. R. Scott (Eds.), Organizational environments: Ritual and rationality (pp. 199-215). Beverly Hills, C.A.: Sage Publications.

Min, W. F. (1999). Global challenges and Chinese responses in higher education. In P. Altbach, \& P. M. Peterson (Eds.), The 21st century: Global challenge and national response. Boston, M.A.: Institute of International Education and Boston College Center for International Higher Education.

Ministry of Education (MOE). (n.d.). Bulletins for national statistics on education and development (1997, 1998, 1999. 2000, 2001, 2002, 2003, and 2004). Retrieved from http://www.moe.edu.cn

MOE. (1984). China education yearbook 1949-1981. Beijing: The Encyclopedia of China Publishing House.

MOE. (1995). Education law. Beijing: The Encyclopedia of China Publishing House.

MOE. (1998). Higher education law. Beijing: The Encyclopedia of China Publishing House.

MOE. (2012). Education informatization: Development plan for ten years (2011-2020). Beijing: China Education Press.

MOE. (2014). Overview of annual report of China's education. Retrieved from http//www.moe.gov.cn/publicfiles/business/ htmlfiles/moe/moe_589/200506/7896.html

Mok, K. H. (2000). Marketing higher education in post-Mao China. International Journal of Educational Development, 20(2), 109-126.

Mok, K. H. (2002). Policy of decentralization and changing governance of higher education in post-Mao China. Public Administration and Development, 22, 261-273.

National Education Committee. (1989). National Education Committee reviews. Beijing: China Education Press.

Oliver, C. (1988). The collective strategy framework: An application to competing predictions of isomorphism. Administrative Science Quarterly, 33(4), 543-561.

Oliver, C. (1991). Strategic responses to institutional processes. The Academy of Management Review, 16(1), 145-179.

Oliver, C. (1992). The antecedents of deinstitutionalization. Organization Studies, 13(4), 563-588. 
Pepper, S. (1990). China's education reform in the 1980s. Oakland, C.A.: The Regents of the University of California.

Pines, A. M. (2002). Teacher burnout: A psychodynamic existential perspective. Teachers and Teaching: Theory and Practice, 8(2), 189-195.

Qiang, L. (1996). China's higher education under reform. International Journal of Educational Management, 17(20), 17-20.

Robertson, R. (1992). Globalization. London, U.K.: Sage.

Rondinelli, D. A., \& Cheema, G. S. (1983). Decentralisation and development: Policy implementation in developing countries. Beverey Hills: Sage.

Rosen, S. (1983). Education and the political socialization of Chinese youths. In J. N. Hawkins (Ed.), Education and social changes in the People's Republic of China. New York, N.Y.: Praeger Publishers.

Sassen, S. (1991). The global city: New York, London, and Tokyo. Princeton, N.J.: Princeton University Press.

Scott, W. R. (1994). Institutions and organizations: Toward a theoretical synthesis. In W. R. Scott, \& J. W. Meyer (Eds.), Institutional environments and organizations: Structural complexity and individualism (pp. 55-80). Thousand Oaks, C.A.: Sage Publications.

Scott, W. R. (2001). Institutions and organizations (2nd ed.). Thousand Oaks, C.A.: Sage Publications.

Scott, W. R. (2003). Organizations: Rational, natural, and open systems (5th ed.). Upper Saddle River, N.J.: Prentice Hall.

Scott, W. R. (2004). Institutional theory: Contributing to a theoretical research program. In K. G. Smith, \& M. A. Hitt (Eds.), Great minds in management: The process of theory development (pp. 460-475). Oxford, U.K.: Oxford University Press.

Selznick, P. (1996). Institutionalism “old” and “new.” Administrative Science Quarterly, 41(2), 270-277.

Shen, L. J. (1997, August 2). Alarm Bells sound for private universities. Worker's Daily, p. 2.

Slaugther, S., \& Leslie, L, (1997). Academic capitalism: Politics, policies and entrepreneurial university. Baltimore: John Hopkins University.

Soros, G. (1998). The crisis of global capitalism. Boston, M.A.: Little, Brown.

Spencer, H. (1910). The principles of sociology (Vol. 3). New York, N.Y.: Appleton-Century-Crofts.

Steward, F. (1996). Globalisation and education. International Journal of Educational Development, 16(4), 327-333.

Stromquist, N. P., \& Monkman, K. (2000). Integration and contestation across cultures (2nd ed.). Lanham, M.D.: Rowman \& Littlefield Education (A division of Rowman \& Littlefield).

Tracy, M. (1997). To transfer power or to transfer responsibility: educational decentralisation in Venezuela. International Journal of Educational Development, 17(2), 145-162.

Wang, X. (1997). Rethinking of higher education in China. Chengdu: Sichuan Normal University Press.

Weber, M. (1924/1946). The theory of social and economic organization. (A. M. Henderson, \& T. Parsons, Translated and edited). New York, N.Y.: Oxford University Press.

Weber, M. (1924/1968). Economy and society: An interpretive sociology. New York, N.Y.: Bedminister Press.

Wing-Wah, L. (1995). The role of the state in higher education reform: Mainland China and Taiwan. Comparative Education Review, 39(3), 322-355.

$\mathrm{Xu}, \mathrm{S}$. H. (2005). The development of China's higher education reforms. Beijing: Beijing Normal University Press.

Yang, X. F. (1987). Works of Yang Xiufeng. Beijing: Beijing Normal University Press.

Yuan, G. R. (2012). Speech on the 2012 National Education Conference. Beijing: China Education Press.

Zhou, J. (2004). China education reports. Beijing: China Education Press.

Zhou, Y. Q. (2000). Higher education management development. China Education Newspaper. 